\title{
JUICE VESICLE POPULATIONS IN CITRUS FRUIT
}

\author{
BRENT TISSERAT, DANIEL JONES, AND PAUL D. GALLETTA
}

U.S. Department of Agriculture, Agricultural Research Service, Fruit and Vegetable Chemistry Laboratory, Pasadena, California 91106

\begin{abstract}
The total number of vesicles within the fruits of several species of the Aurantioideae (Rutaceae) was determined. Two distinct vesicle shape types are recognized: superior and inferior. There was a significant correlation with the number of juice vesicles per fruit and the number of segments found within the fruit. Citrus species (e.g., grapefruit and pummelo) containing fruit composed of many segments (e.g., 10-14 and 20 , respectively) correspondingly contained more vesicles per segment than those citrus species (e.g., kumquat and mandarin) containing fruit with few segments (4 and 7-10, respectively). Significant correlations were found between vesicle number and segment area or segment weight. Large segments weighed more and contained more vesicles than small segments. Seed number per fruit or per segment did not have significant correlation with the number of vesicles produced per fruit or per segment. A formula, based upon a partial fruit analysis, to estimate the total number of vesicles in a fruit within $5 \%$ of the actual number is presented. The number of vesicles produced in fruit was found to be influenced by environment. Fruit from trees of 'Eureka' lemon and 'Improved' Meyer lemons grown inside a temperature controlled greenhouse contained more vesicles than fruit from trees grown outdoors.
\end{abstract}

\section{Introduction}

The hesperidium is a fruit type unique to the subfamily Aurantioideae, family Rutaceae, and is produced by six genera commonly known as the "true citrus fruit group": Citrus, Clymenia, Eremocitrus, Fortunella, Microcitrus, and Poncirus (SWINGLE and REECE 1967). The hesperidium is a kind of berry composed of a leathery rind and divided internally into segments (i.e., fused carpels or locules). These segments are triangularly lunate in shape and produce the pulp vesicles on their inner surface. All six genera produce vesicles that are quite similar in appearance, but only those juice vesicles found in Fortunella and Citrus are edible (HodGSON 1967; SwINGLE and ReECE 1967). Vesicle histological development has been described in several Citrus species including: lemon (C. limon L. Burm. cv Eureka) (FORD 1942), navel orange (C. sinensis L. Osb.) (Osawa 1912), pummelo (C. grandis L. Osb.) (BANERJI 1954), Valencia orange (C. sinensis) (BAIN 1958; SCHNEIDER 1968), and the Satsuma mandarin (C. unshiu Marc.) (NII and COOMBE 1988). Vesicle initiation and development was found to be similar in all citrus species (NII and COOMBE 1988). To summarize these past studies, juice vesicles are initiated just before or during anthesis as multicellular primordial bulges on the locular side of the endocarp surface usually on the radial wall. These primordia are initiated by anticlinal divisions in endocarp cells and by periclinal divisions in the neighboring subepidermal

Manuscript received March 1989; revised manuscript received September 1989.

Address for correspondence and reprints: BRENT TISSERAT, U.S. Department of Agriculture, Agricultural Research Service, Fruit and Vegetable Chemistry Laboratory, Pasadena, California 91106. layers. Vesicles then successively manifest club, conical, and, eventually, elliptical shapes. The mature vesicles are elliptical multicellular sacs enclosed by a membrane, usually containing a minute oil gland in their center and connected to the segment wall by a multicellular stalk (FORD 1942; SCHNEIDER 1968).

Two reports mention the number of vesicles found in citrus fruit (BAIN 1959; NII and COOMBE 1988). NiI and CoOmbe (1988) state that more than two hundred juice vesicles occur per segment in mandarins, although a precise number is not given. BAIN (1959), in contrast, performed intensive vesicle counts in three fruit of Valencia orange. The number of juice sacs per segment varied considerably in Valencia oranges. As many as 651 vesicles could occur in a segment, while the average segment had 356 to 578 vesicles. It was suggested that the size of the segment and the number of seeds present in the segment might influence the number of vesicles produced per segment. Those segments containing seeds had fewer vesicles than those without seeds, and larger segments had more vesicles than smaller ones (BAIN 1959).

The size, shape, chemical composition, and marketability of citrus fruit is dependent upon its juice vesicle population (HoDGSON 1967). Despite such obvious importance, little is known about the total number of vesicles occurring within a fruit, their distribution or dimensions within a segment or even if the number of vesicles in a fruit can be altered. The preponderance of citrus fruit chemical studies have been concerned with post-harvest pulp analyses and not with factors specifically affecting the morphological development of the juice vesicles (REED 1930; HAAS and KLOTZ 1935; BARTHOLOMEW and SINCLAIR 1941; SINCLAIR and BARTHOLOMEW 1944; SINCLAIR and RAMSEY 1944; 
MARLOTh 1950; SAUER 1953; Coggins et al. 1960; REUTHER 1980; Boswell et al. 1982). This study was conducted to determine (1) the number of vesicles occurring within various citrus fruits and (2) whether the vesicle population could be altered through experimental treatments.

\section{Material and methods}

Citropsis gabunensis (Engl.) Swing. and M. Kell. (Gabon cherry-orange), Citrus aurantium L. (sour orange), C. grandis, C. hystrix DC. (papeda), $C$. limon, $C$. medica, C. meyerii Y. Tan. (Meyer lemon), C. miaray West., C. paradisi Macf. (grapefruit), C. reticulata Blanco (mandarin), $C$. sinensis (sweet orange), C. unshiu, Fortunella margarita (Lour.) Swing. (kumquat), and Poncirus trifoliata L. Raf. (trifoliate orange) were studied. Fruit was collected from 6-yr-old trees grown in the Citrus Variety Collection at the University of California, Riverside. Initially, many stages and sizes of fruit development were examined to determine the optimum stage for use in population counts. In order to facilitate accurate vesicle counts, immature green fruits (about 150-80 d old) containing young, firm, early elliptical-shaped vesicles were employed. Two to four fruits per tree for each species cultivar were usually used in vesicle counts. Fruits were peeled and carefully separated into segments using the dull end of a spatula. Length, equatorial width, and weight of separated segments were measured. Segment area was calculated by multiplying the equatorial width by the length. Vesicle counts were made sequentially from the stylar end to stem end. Each counted vesicle was detached to prevent counting mistakes. Vesicles were counted with the aid of a dissecting microscope at 6-50 $\times$ magnification. During these counts, seed number per segment was also determined. Length (stalk and body), width (body only), and weight of vesicles were measured.

To determine the influence of specific environments on vesicle populations within fruits, 4-yr-old trees of cv Eureka lemon and cv Meyer Improved lemon were grown in a temperature controlled greenhouse in Pasadena, California, where the temperature during daytime and nighttime was maintained at 23-27 C and 16-20 C, respectively, for $2 \mathrm{yr}$. Outside temperature conditions during daytime and nighttime were 20-33 C and 13-30 $\mathrm{C}$, respectively. Maximum illumination was determined to be 2,000 $\mu$ moles $\mathrm{m}^{-2} \mathrm{~s}^{-1}$ outside and 1,700 $\mu$ moles $\mathrm{m}^{-2} \mathrm{~s}^{-1}$ in the greenhouse. Trees in the greenhouse were grown in a sandy-loam soil while trees outside were in a clay-loam soil. Similar watering and fertilizing practices were administered to the trees grown both outside and inside the greenhouse. Fruit set within greenhouse and outdoor conditions were analyzed for vesicle populations.

\section{Observations}

\section{VESICLE DEVELOPMENT AND NUMBER IN FRUITS}

Invariably, the population of vesicles occurring within each segment was heterogeneous in size, weight, and shape-type (figs. 1-4). Vesicles exhibited two distinct shape-types within the segment: superior and inferior (fig. 1). About $55 \%$ and $45 \%$ of the vesicles occurring within the segment were inferior and superior shape-types, respectively. The superior vesicle is characterized as being well formed with a stalk that is often as long as the vesicle body. The bulk of the superior vesicle body is physically located above the inferior vesicles, viewing the cross section of the segment. The slender stalks of superior vesicles thread between the underlying inferior vesicles and attached to the endocarp. Superior vesicles most often occur in the equatorial region of the fruit (fig. 2). In grapefruit and pummelo vesicles were found to have a close association with the vascular bundles (fig. 2). Vascular bundles in these fruits occur close to the surface of the endocarp tissue and are directly connected to the vesicle stalks. In lemons, however, no vascular association was found between the vascular bundles and the vesicles (fig. 2). Lemon vascular bundles occurred several cell layers deep within the mesocarp compared to vascular bundle location in grapefruits. The inferior vesicles are characterized by a short stalk, about one-quarter to one-half the length of the vesicle body length. The body of the inferior vesicle may be somewhat irregular but still retains the elliptical shape. Inferior vesicles occur beneath the superior ones and are densely compressed together. Regardless of the shape-type, vesicles at the equatorial region were often greater in length and more numerous than vesicles occurring at the extreme stem or extreme stylar ends (figs.

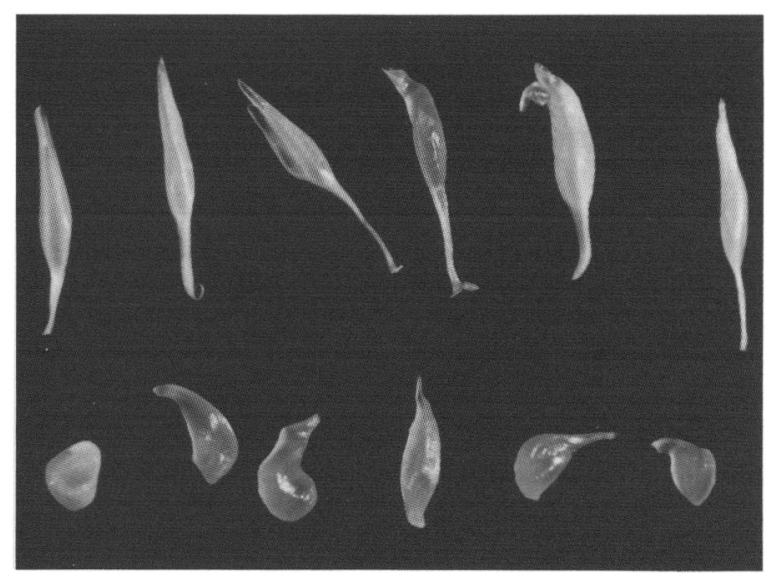

Fig. 1.-Examples of superior (top row) and inferior (bottom row) juice vesicle shapes found in a $40-\mathrm{mm}$ diameter $C i t$ rus limon cv Eureka lemon fruit. Note that the inferior vesicles have a somewhat irregular elliptical shape. $B a r=10 \mathrm{~mm}$. 


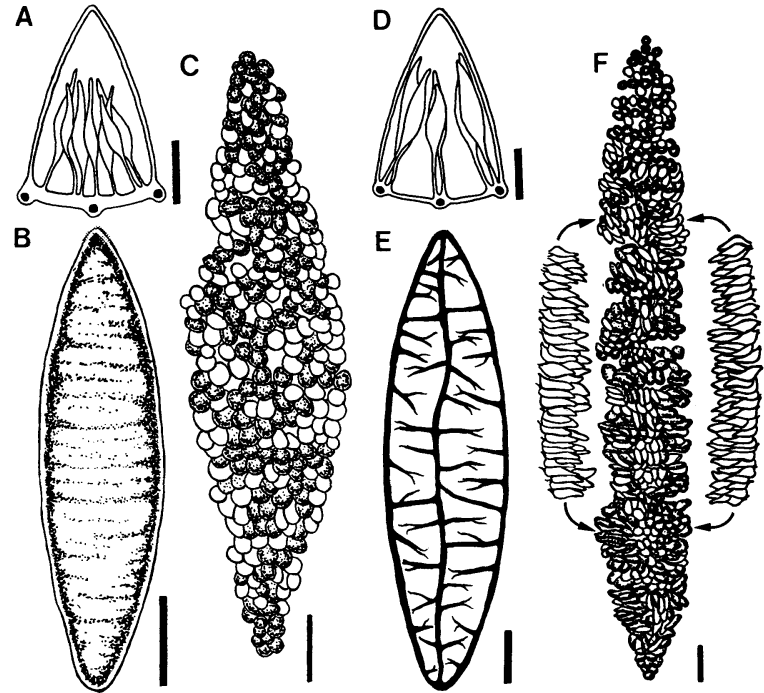

FIG. 2.-Location of vesicle types within a Citrus limon cv Eureka lemon segment $(A-C)$ and a $C$. paradisi cv Seedy Marsh $(D-F)$. Diagrammatic top view of location of inferior (shaded) and superior (nonshaded) within a segment $(C$ and $F)$. Grapefruit superior vesicles along the tangential wall are pulled out for illustration $(F)$. Segment endocarp surface with vesicles removed $(B$ and $E$ ). Vascular bundle tissues are illustrated as being located beneath the endocarp surface in lemons $(B)$ or near the endocarp surface in grapefruits $(E)$. Attachment of vesicles to tissue adjacent to vascular bundles is illustrated in cross sections $(A$ and $D)$. Note that the grapefruit vesicles are attached to the tissue immediately in contact with vascular bundles $(D)$ while lemon vesicles occur independent of the vascular bundle tissue $(A)$. Bar $=5 \mathrm{~mm}$.

$2,3)$. However, vesicles in the extreme ends generally weighed more than equatorial vesicles (fig. 4). The distribution of vesicles among segments within the same fruit was similar (fig. 3). The unattached terminal ends of all vesicles exhibit a distinct orientation within the carpel; these terminals point slightly toward the stylar end of the fruit. The seeds within the segment are oriented so that the chalazal end extends toward the stem end and the micropylar end extends toward the stylar end of the fruit.

Most citrus fruit possess roughly $130-400$ vesicles per segment (table 1). Pummelo fruits contain the most vesicles per fruit, followed in order of decreasing vesicles per fruit by grapefruit, citron, sweet orange, meyer lemon, papeda, lemon, sour orange, mandarin, Satsuma mandarin, Citrus miaray, trifoliate orange, Gabon cherry-orange, and kumquat. The number of vesicles found in fruits is related to the number of segments per fruit and the genotype. Pummelos, grapefruits, and citrons that contained the most segments per fruit (ca. 12-20) and are also have the largest fruit sizes, in terms of diameter, also contained the highest number of

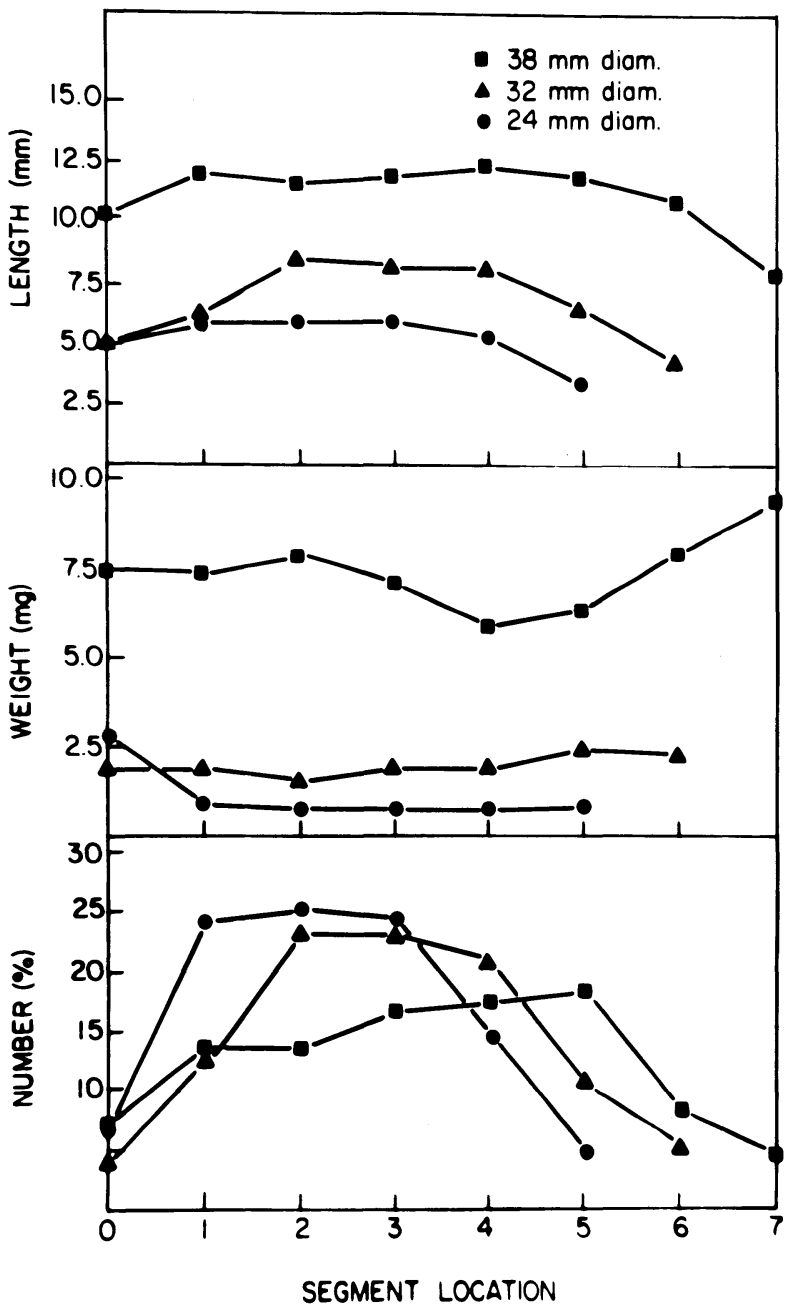

FIG. 3.-Relationship between vesicle number, weight, and length found in segments of three different sized Citrus limon cv Eureka lemon fruit. Segment locations are divided into equal $(0.5 \mathrm{~cm})$ partitions with 0 representing that portion closest to the style and 7 being closest to the stem end.

vesicles per fruit and the highest number of vesicles per segment (about 300-500 vesicles). Cultivar Imperial grapefruit, lemon, mandarin, papeda, sour oranges, and sweet oranges produced about 200-300 vesicles per segment, contain about 8-11 segments per fruit, and are smaller sized fruits. Citrus miaray and Satsuma mandarin, which contain 10 and 7-9 segments per fruit, respectively, produce fewer than 200 vesicles per segment, and are proportionately smaller fruits. Close citrus relatives Gabon cherry-orange, kumquat, and trifoliate orange produce fewer than 200 vesicles per segment and contain the fewest number of segments per fruit (ca. 4-7) (table 1). It should be noted that fruit size for these citrus relatives were porportionately smaller. 


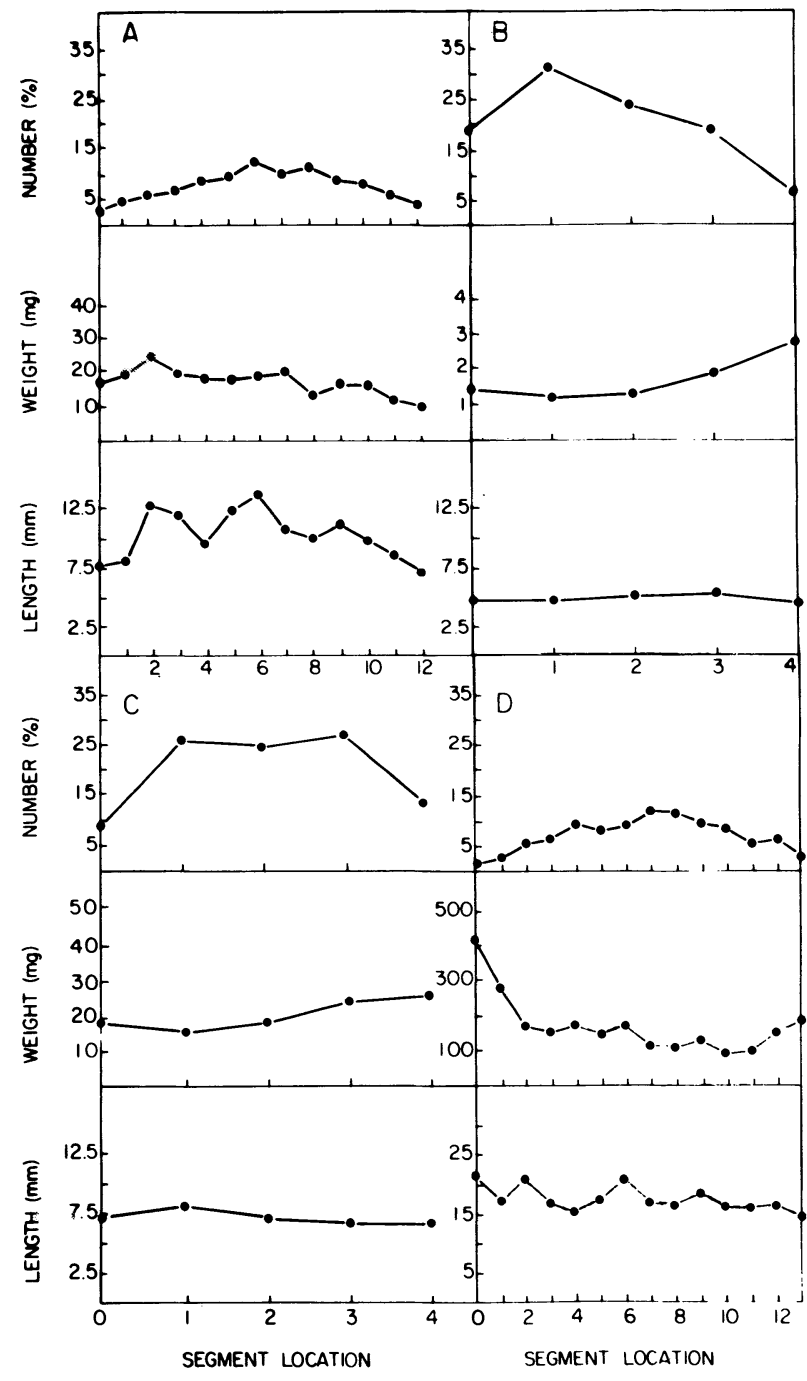

FIG. 4.-Relationship of vesicle number, weight, or length to location in the segment of various Citrus species. A, C. medica cv Philippine $60-\mathrm{mm}$ diameter fruit; $B, C$. sinensis cv Cutter 20-mm diameter fruit; $C, C$. reticulata cv Fortune Frost 25$\mathrm{mm}$ diameter fruit; and $D, C$. grandis cv Siamese Acidless 65$\mathrm{mm}$ diameter fruit. Segment location is divided into $0.5-\mathrm{cm}$ partitions with 0 representing that portion closest to the style and the largest number being closest to the stem end.

\section{CORRELATIONS OF VESICLE NUMBER WITH SEGMENT WEIGHT, SEGMENT AREA, AND SEGMENT SEED NUMBER}

For most species, there was a significant correlation between the number of vesicles in a segment and its weight or area (table 2). In $80 \%$ of the citrus fruit measured, segments with greater weight contained more vesicles than segments of lesser weight. In terms of area, over $90 \%$ of the fruit measured exhibited a significant correlation between segment area and the number of vesicles present. Seed number was not found to be corre- lated with vesicle number; only $18 \%$ of all the cultivars measured showed any significant correlation between number of seeds and the number of vesicles (table 2).

\section{ESTIMATION OF VESICLES IN FRUIT}

A relationship was found between the number of vesicles and segments within the fruit, thereby enabling an estimation of the total number of vesicles in the fruit (fig. 5; table 3). For numerous species, vesicles within each segment were counted, cumulatively summed, and averaged. The estimate of the total number of vesicles per fruit was obtained by multiplying the average number of vesicles per segment counted by the total number of segments present in the fruit. In this estimation process, no attention was given to segment dimensions because segments were counted in sequence. For fruits with fewer than 12 segments, counts of three segments were sufficient to obtain the total number of vesicles within a fruit within a 5\%-10\% accuracy compared to counting all segments (fig. 5). However, more segments, i.e., 5-7, need to be counted in order to obtain the same accuracy range for grapefruits, citrons, and pummelos. These species usually contain over 12 segments and therefore have larger variations occurring in their vesicle populations. This results in larger estimation errors.

\section{INFLUENCE OF ENVIRONMENTS ON VESICLE NUMBERS}

The population of vesicles found within $\mathrm{cv}$ Eureka lemon or cv Improved Meyer lemon increased significantly if the trees were grown in a temperature-controlled greenhouse compared to trees grown outdoors (table 4). Segment numbers for fruits collected outdoors or in the greenhouse were not significantly different. Seed number again did not seem to play a part in determining the number of vesicles produced per fruit since fruits set inside the greenhouse rarely contained seeds (table 4).

\section{Discussion}

Although the mode of vesicle origin and development has been documented in lemon (FORD 1942), Valencia orange (BAIN 1958; SCHNEIDER 1968), and pummelo (BANERJI 1954) the occurrence of distinct vesicle shape-types has not been mentioned. Vesicles within citrus fruits are very heterogeneous in appearance and in weight.

Only a limited number of fruit per cultivar were counted in this study due to the time required to conduct such a survey. Individual vesicle counting is tedious, time-consuming, and impractical for large survey numbers. The partial fruit analysis formula for estimating the total number of vesicles per fruit reduces the counting process considerably.

Based on the evidence presented in this study, 
TABLE 1

VESICLE POPULATIONS IN CITRUS FRUIT AND THEIR PROPORTION TO SEED AND SEGMENT NUMBERS

\begin{tabular}{|c|c|c|c|c|c|}
\hline Genus, species, cultivar & $\begin{array}{l}\text { Segments/ } \\
\text { fruit }\end{array}$ & $\begin{array}{l}\text { Vesicles/ } \\
\text { fruit }\end{array}$ & $\begin{array}{l}\text { Seeds/ } \\
\text { fruit }\end{array}$ & $\begin{array}{l}\text { Vesicles/ } \\
\text { segment }\end{array}$ & $\begin{array}{l}\text { Vesicles/ } \\
\text { seed }\end{array}$ \\
\hline \multicolumn{6}{|l|}{ Citropsis gabunensis: } \\
\hline Unknown $\ldots \ldots \ldots \ldots$ & 4 & 687 & 39 & 171.5 & 17.6 \\
\hline Unknown ............ & 4 & 710 & 43 & 177.5 & 16.5 \\
\hline Average $\ldots \ldots \ldots$ & $4.0 \pm 0.00$ & $698.5 \pm 11.50$ & $41.0 \pm 2.00$ & $174.5 \pm 3.00$ & $17.1 \pm .55$ \\
\hline \multicolumn{6}{|l|}{$\begin{array}{l}\text { Citrus: } \\
\quad \text { aurantium: }\end{array}$} \\
\hline Standard & 11 & 2,320 & 18 & 210.9 & 128.9 \\
\hline Standard & 10 & 1,932 & 57 & 193.2 & 33.9 \\
\hline Standard & 10 & 2,026 & 50 & 202.6 & 40.5 \\
\hline $\begin{array}{c}\text { Average } \ldots \ldots \ldots \\
\text { grandis: }\end{array}$ & $10.3 \pm .33$ & $2,092.6 \pm 116.86$ & $41.7 \pm 12.01$ & $202.2 \pm 5.11$ & $67.8 \pm 30.63$ \\
\hline Siamese Acidless .... & 20 & 6,402 & 134 & 320.1 & 47.8 \\
\hline Siamese Acidless .... & 20 & 10,224 & 190 & 511.2 & 53.8 \\
\hline Average ........ & $20.0 \pm 0$ & $8,313.0 \pm 1911.00$ & $162.0 \pm 28.00$ & $415.6 \pm 95.55$ & $50.8 \pm 3.00$ \\
\hline \multicolumn{6}{|l|}{ hystrix: } \\
\hline Cabuyao ............ & 10 & 2,708 & 19 & 270.8 & 142.5 \\
\hline Cabuyao ............. & 10 & 2,623 & 17 & 262.3 & 154.3 \\
\hline Average $\ldots \ldots \ldots$ & $10.0 \pm 0$ & $2,665.5 \pm 42.50$ & $18.0 \pm 1.00$ & $266.5 \pm 4.25$ & $148.4 \pm 6.00$ \\
\hline \multicolumn{6}{|l|}{ limon: } \\
\hline Eureka $\ldots \ldots \ldots \ldots$ & 11 & 2,504 & 22 & 227.6 & 113.8 \\
\hline Eureka $\ldots \ldots \ldots \ldots$ & 10 & 2,325 & 17 & 232.5 & 136.8 \\
\hline Eureka $\ldots \ldots \ldots \ldots$ & 10 & 2,666 & 25 & 266.6 & 106.6 \\
\hline Eureka & 10 & 2,467 & 25 & 246.7 & 98.7 \\
\hline $\begin{array}{l}\text { Average } \ldots \ldots \ldots \\
\text { medica: }\end{array}$ & $10.2 \pm .25$ & $2,490.5 \pm 70.07$ & $22.2 \pm 1.89$ & $243.4 \pm 8.74$ & $114.0 \pm 8.21$ \\
\hline Diamante $\ldots . . . \ldots$ & 8 & 1,965 & 76 & 245.6 & 25.9 \\
\hline Diamante $\ldots . \ldots \ldots$ & 13 & 4,010 & 101 & 308.5 & 39.7 \\
\hline Average $\ldots . . . \ldots$ & $10.5 \pm 2.50$ & $2,987.5 \pm 1022.50$ & $88.5 \pm 12.50$ & $277.0 \pm 31.45$ & $32.8 \pm 6.90$ \\
\hline Philippine . . . . . . . & 13 & 4,504 & 75 & 346.5 & 60.1 \\
\hline Philippine $\ldots \ldots \ldots$ & 10 & 5,869 & 98 & 586.9 & 59.9 \\
\hline Average...$\ldots \ldots$ & $11.5 \pm 1.50$ & $5,186.5 \pm 682.5$ & $86.5 \pm 11.50$ & $466.7 \pm 120.20$ & $60.0 \pm .10$ \\
\hline \multicolumn{6}{|l|}{ meyerii: } \\
\hline Improved $\ldots \ldots \ldots$ & 10 & 2,615 & 14 & 261.5 & 186.8 \\
\hline Improved $\ldots \ldots \ldots$ & 10 & 2,845 & 11 & 284.5 & 258.6 \\
\hline Improved $\ldots \ldots \ldots$ & 10 & 2,721 & 12 & 272.1 & 226.8 \\
\hline $\begin{array}{l}\text { Average } \ldots \ldots \ldots \\
\text { miaray: }\end{array}$ & $10.0 \pm 0$ & $2,727.0 \pm 66.46$ & $12.3 \pm .88$ & $272.7 \pm 6.65$ & $224.1 \pm 20.77$ \\
\hline Unknown $\ldots . . \ldots \ldots$ & 10 & 1,368 & 24 & 136.8 & 57 \\
\hline Unknown $\ldots \ldots \ldots$ & 10 & 1,289 & 17 & 128.9 & 75.8 \\
\hline 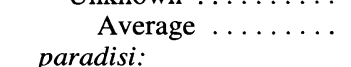 & $10.0 \pm 0$ & $1,328.5 \pm 55.86$ & $20.5 \pm 3.50$ & $132.9 \pm 3.95$ & $66.4 \pm 9.40$ \\
\hline 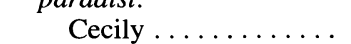 & 10 & 3,198 & 74 & 319.8 & 43.2 \\
\hline Cecily ........... & 13 & 4,628 & 53 & 356 & 87.3 \\
\hline Average $\ldots \ldots \ldots$ & $11.5 \pm 1.50$ & $3,913.0 \pm 715.00$ & $63.5 \pm 10.50$ & $337.9 \pm 18.10$ & $65.3 \pm 22.50$ \\
\hline Hudson Foster . . . . . & 11 & 2,775 & 51 & 252.3 & 54.4 \\
\hline Hudson Foster ...... & 10 & 3,413 & 63 & 341.3 & 54.2 \\
\hline Average & $10.5 \pm .50$ & $3,094.0 \pm 319.00$ & $57.0 \pm 8.45$ & $296.8 \pm 44.50$ & $54.3 \pm .10$ \\
\hline Imperial .. & 12 & 2,683 & 53 & 223.6 & 50.6 \\
\hline Imperial $\ldots \ldots \ldots \ldots$ & 14 & 2,168 & 76 & 154.9 & 28.5 \\
\hline $\begin{array}{c}\text { Average } \ldots \ldots \ldots \\
\text { reticulata. }\end{array}$ & $13.0 \pm 1.00$ & $2,425.5 \pm 257.50$ & $64.5 \pm 11.50$ & $189.2 \pm 34.35$ & $39.6 \pm 11.05$ \\
\hline $\begin{array}{l}\text { rettculata: } \\
\text { Fortune Frost }\end{array}$ & 10 & 2,022 & 22 & 202.2 & 91.9 \\
\hline Fortune Frost $\ldots \ldots \ldots$ & 9 & 2,358 & 18 & 262.0 & 131.0 \\
\hline $\begin{array}{l}\text { Average } . . . \ldots \ldots \\
\text { sinensis: }\end{array}$ & $9.5 \pm .50$ & $2,190.0 \pm 168.00$ & $20.0 \pm 2.00$ & $232.1 \pm 29.90$ & $111.5 \pm 19.55$ \\
\hline Homosassa & 9 & 2,231 & 22 & 247.9 & 101.4 \\
\hline Homosassa . . . . . . . & 10 & 2,026 & 50 & 202.6 & 40.5 \\
\hline Homosassa ........ & 11 & 3,067 & 14 & 278.8 & 219.1 \\
\hline Average $\ldots \ldots$ & $10.0 \pm .577$ & $2,441.3 \pm 318.38$ & $28.7 \pm 18.90$ & $243.1 \pm 22.13$ & $120.3 \pm 52.42$ \\
\hline Robertson (Navel) ... & 10 & 2,174 & 0 & 217.4 & $*$ \\
\hline Robertson (Navel) ... & 10 & 2,710 & 0 & 271.0 & $*$ \\
\hline Average $\ldots \ldots \ldots$ & $10.0 \pm 0$ & $2,442.0 \pm 268.00$ & $0 \pm 0$ & $244.2 \pm 26.80$ & * \\
\hline Cutter (Valencia) .... & 9 & 4,101 & 6 & 455.7 & 683.5 \\
\hline Cutter (Valencia) .... & 10 & 3,546 & 4 & 354.6 & 886.5 \\
\hline $\begin{array}{l}\text { Average } \ldots \ldots \ldots \\
\text { unshiu: }\end{array}$ & $9.5 \pm .50$ & $3,823.5 \pm 277.50$ & $5.0 \pm 1.00$ & $405.1 \pm 50.55$ & $785.0 \pm 101.50$ \\
\hline Satsuma Frost...... & 9 & 1,430 & 0 & 158.9 & * \\
\hline Satsuma Frost....... & 9 & 1,563 & 1 & 173.7 & 1563 \\
\hline
\end{tabular}


TABLE 1 (Continued)

\begin{tabular}{|c|c|c|c|c|c|}
\hline Genus, species, cultivar & $\begin{array}{l}\text { Segments / } \\
\text { fruit }\end{array}$ & $\begin{array}{l}\text { Vesicles/ } \\
\text { fruit }\end{array}$ & $\begin{array}{l}\text { Seeds / } \\
\text { fruit }\end{array}$ & $\begin{array}{l}\text { Vesicles/ } \\
\text { segment }\end{array}$ & $\begin{array}{c}\text { Vesicles/ } \\
\text { seed }\end{array}$ \\
\hline Satsuma Frost . . . . . . & 7 & 1,663 & 2 & 237.6 & 831.5 \\
\hline Average $\ldots \ldots \ldots$ & $8.3 \pm .667$ & $1,552.0 \pm 67.49$ & $1.0 \pm .58$ & $190.0 \pm 24.15$ & $1197.2 \pm 365.70$ \\
\hline \multicolumn{6}{|l|}{ Fortunella margarita: } \\
\hline Nagami . . . . . . . . . . . & 4 & 605 & 3 & 151.2 & 201.7 \\
\hline Nagami . . . . . . . . . & 5 & 570 & 4 & 114.0 & 142.5 \\
\hline Average $\ldots . \ldots \ldots$ & $4.5 \pm .5$ & $587.5 \pm 17.50$ & $3.5 \pm .50$ & $132.6 \pm 18.60$ & $172.1 \pm 18.60$ \\
\hline \multicolumn{6}{|l|}{ Poncirus trifoliata: } \\
\hline Webber-Fawcett . . . . . . & 6 & 1,090 & 39 & 181.7 & 27.9 \\
\hline Webber-Fawcett . . . . . . & 7 & 1,361 & 31 & 194.4 & 43.9 \\
\hline Average $\ldots \ldots \ldots \ldots$ & $6.5 \pm .50$ & $1,225.5 \pm 135.5$ & $35.0 \pm 4.00$ & $188.0 \pm 6.35$ & $35.9 \pm 8.00$ \\
\hline
\end{tabular}

Note. - Averages and standard errors are presented. No seeds were found in fruits with the $*$ designations.

TABLE 2

CORRELATION BETWEEN VESICLE NUMBER TO SEGMENT AREA, SEGMENT WEIGHT, OR SEED NUMBER IN CITRUS FRUITS

\begin{tabular}{|c|c|c|c|c|c|}
\hline Genus, species, cultivar & $\begin{array}{l}\text { Vesicles/ } \\
\text { segment }\end{array}$ & Area $\left(\mathrm{cm}^{2}\right) /$ segment & Weight (g)/segment & Seeds/segment & $\begin{array}{l}\text { Segment } \\
\text { no. }\end{array}$ \\
\hline \multicolumn{6}{|l|}{ Citrus: } \\
\hline \multicolumn{6}{|l|}{ aurantium: } \\
\hline Standard $\ldots \ldots \ldots$ & $265.8 \pm 11.4$ & $6.3 \pm .33(.836) \mathrm{S}$ & $14.3 \pm .63(.690) \mathrm{S}$ & $2.7 \pm 1.30(.533)$ & 10 \\
\hline Standard $\ldots \ldots \ldots$ & $292.0 \pm 19.6$ & $2.6 \pm .12(.405)$ & $4.0 \pm .17(.638) S$ & $2.5 \pm .52(.009)$ & 10 \\
\hline Standard $\ldots \ldots \ldots$ & $210.9 \pm 9.6$ & $1.2 \pm .06(.387)$ & $1.1 \pm .07(.741) \mathrm{S}$ & $1.6 \pm .41(.194)$ & 11 \\
\hline $\begin{array}{l}\text { Standard } \ldots \ldots \\
\text { grandis: }\end{array}$ & $193.2 \pm 7.2$ & $5.4 \pm .31(.133)$ & $9.9 \pm .32(.817) \mathrm{S}$ & $5.7 \pm .30(.504)$ & 10 \\
\hline Yuma Ponderosa . . & $434.9 \pm 19.9$ & $7.9 \pm .36(.417)$ & $23.5 \pm .84(.700) S$ & $4.8 \pm .44(.166)$ & 10 \\
\hline $\begin{array}{l}\text { Yuma Ponderosa. . } \\
\text { hystrix: }\end{array}$ & $596.2 \pm 45.8$ & $.5 \pm .03(.821) \mathrm{S}$ & $\ldots$ & $8.1 \pm .87(.592)$ & 11 \\
\hline $\begin{array}{l}\text { Cabuyao } \ldots \ldots \ldots \\
\text { limon: }\end{array}$ & $270.8 \pm 16.8$ & $1.5 \pm .09(.801) \mathrm{S}$ & $2.2 \pm .12(.857) \mathrm{S}$ & $2.0 \pm .42(-.257)$ & 10 \\
\hline Eureka . . . . . . . . & $346.9 \pm 15.2$ & $4.7 \pm .28(.898) S$ & $6.4 \pm .34(.943) S$ & $1.5 \pm .33(.282)$ & 8 \\
\hline Eureka ......... & $289.2 \pm 16.9$ & $4.2 \pm .20(.892) \mathrm{S}$ & $6.5 \pm .34(.949) \mathrm{S}$ & $2.5 \pm .56(.105)$ & 10 \\
\hline $\begin{array}{l}\text { Eureka } \ldots \ldots \cdots \\
\text { medica: }\end{array}$ & $229.7 \pm 14.0$ & $4.1 \pm .22(.737) \mathrm{S}$ & $4.3 \pm .26(.846) S$ & $2.0 \pm .42(.094)$ & 10 \\
\hline Diamante . . . . . . . . & $245.6 \pm 31.1$ & $2.4 \pm .33(.762) \mathrm{S}$ & $2.8 \pm .40(.825) \mathrm{S}$ & $9.9 \pm 1.45(.670)$ & 8 \\
\hline $\begin{array}{l}\text { Diamante } \ldots \ldots \\
\text { meyerii: }\end{array}$ & $404.0 \pm 35.0$ & \multicolumn{3}{|c|}{ meyerii: } & 11 \\
\hline Improved . & $261.5 \pm 9.8$ & $4.5 \pm .15(.819) \mathrm{S}$ & $7.8 \pm .31(.833)$ & $1.4 \pm .43(.082)$ & 10 \\
\hline Improved . . . . . . . & $291.5 \pm 16.6$ & $3.7 \pm .20(.592) S$ & $6.7 \pm .48(.835) \mathrm{S}$ & $1.1 \pm .27(.365)$ & 10 \\
\hline Improved . . . . . . & $302.3 \pm 23.6$ & $4.4 \pm .31(.917) S$ & $6.4 \pm .46(.937) \mathrm{S}$ & $1.2 \pm .32(.408)$ & 9 \\
\hline \multicolumn{6}{|l|}{ miaray: } \\
\hline Unknown . . . . . . & $136.8 \pm 9.3$ & $1.7 \pm .07(.692) \mathrm{S}$ & $2.7 \pm .16(.717) S$ & $2.3 \pm .3(.306)$ & 10 \\
\hline \multicolumn{6}{|l|}{ paradisi: } \\
\hline Cecily $\ldots . \ldots \ldots$ & $319.0 \pm 17.9$ & $8.3 \pm .42(.750) \mathrm{S}$ & $21.9 \pm 1.68(.884) \mathrm{S}$ & $.6 \pm .22(0.46)$ & 10 \\
\hline Cecily ........ & $356.0 \pm 25.5$ & $8.6 \pm .92(.864) S$ & $19.6 \pm .88(.884) \mathrm{S}$ & $4.0 \pm .08(-.069)$ & 10 \\
\hline Duncan ........ & $348.3 \pm 22.3$ & $4.8 \pm .24(.682) S$ & $12.0 \pm .77(.921) \mathrm{S}$ & $6.3 \pm .65(.601) S$ & 10 \\
\hline Hudson Foster . . . . & $252.3 \pm 22.8$ & $6.6 \pm .79(.885) \mathrm{S}$ & $12.1 \pm 1.00(.588) \mathrm{S}$ & $4.6 \pm .41(.576) S$ & 11 \\
\hline Imperial . . . . . . . & $221.9 \pm 15.1$ & $8.2 \pm .56(.884) \mathrm{S}$ & $17.5 \pm .86(.866) S$ & $4.6 \pm .34(.613) S$ & 13 \\
\hline \multicolumn{6}{|l|}{ reticulata: } \\
\hline Fortune $\ldots \ldots \ldots$ & $202.2 \pm 9.4$ & $5.5 \pm .09(.762) \mathrm{S}$ & $8.6 \pm .60(.383)$ & $2.7 \pm .30(.269)$ & 10 \\
\hline $\begin{array}{l}\text { Fortune } \ldots \ldots \cdots \\
\text { sinensis: }\end{array}$ & $262.0 \pm 12.8$ & $4.0 \pm .18(.740) S$ & $5.9 \pm .32(.614)$ & $2.0 \pm .47(.124)$ & 9 \\
\hline Cutter. . . . . . . . . & $467.6 \pm 25.3$ & $4.1 \pm .18(.699) \mathrm{S}$ & $5.4 \pm .24(.809) \mathrm{S}$ & $.6 \pm .20(.334)$ & 7 \\
\hline \multicolumn{6}{|l|}{ unshiu: } \\
\hline Satsuma Frost .... & $158.9 \pm 13.0$ & $4.2 \pm .35(.972) \mathrm{S}$ & $\ldots$ & $0 \pm 0$ & 9 \\
\hline Satsuma Frost . . . . & $173.7 \pm 13.7$ & $4.7 \pm .53(.952) S$ & $\cdots$ & $.1 \pm .11(.579)$ & 9 \\
\hline \multicolumn{6}{|l|}{ Poncirus trifoliata: } \\
\hline Webber-Fawcett . & $181.7 \pm 9.5$ & $4.0 \pm .16(.918) S$ & $5.5 \pm 1.16(.441)$ & $6.5 \pm .89(.895) S$ & 6 \\
\hline Webber-Fawcett .... & $194.4 \pm 8.9$ & $1.9 \pm .17(.675)$ & $2.2 \pm .32(.870) S$ & $4.3 \pm .64(.883) S$ & 7 \\
\hline
\end{tabular}

NoTE.-Correlation coefficients are presented in parentheses from comparing vesicles/segment with area/segment, weight/ segment, or seeds/segment. Treatment means within the same row showed significant (S) correlation or nonsignificant (no designation) correlation using the correlation coefficient test $(P<.05)$. 

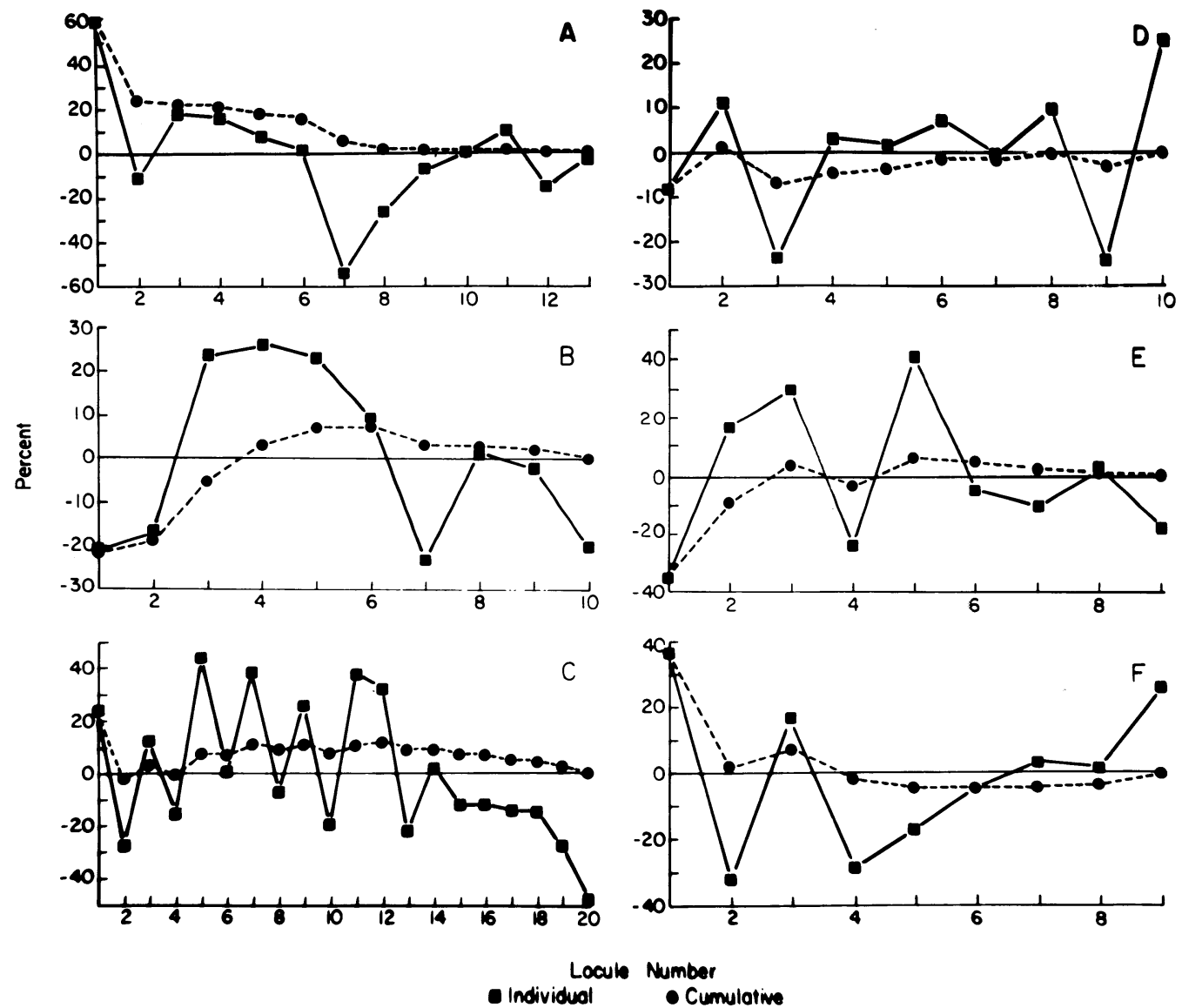

Fig. 5.-Comparison between two estimation methods to determine the total number of vesicles occurring within a Citrus fruit: (1) multiplying the number of segments by the number of vesicles found in each segment (solid lines) and (2) dividing the cumulative total of vesicles counted in all segments by the segments counted and then multiplying by the total number of segments (dotted lines). Percentage of error using the two estimating methods compared to the actual number of vesicles occurring within the fruit is presented. $A, C$. medica cv Philippine; $B, C$. sinensis cv Homosassa; $C, C$. grandis cv Siamese Acidless; $D, C$. sinensis cv Cutter; $E, C$. reticulata cv Fortune Frost; and $F, C$. paradisi cv Duncan. Estimates from individual segment counts may give rise to large errors.

TABLE 3

Methods to estimate the tOTAL NUMBER OF VeSiCles IN A 50-mm DiAMETER SWEET ORANGe (Citrus sinensis cv Homosassa)

\begin{tabular}{|c|c|c|c|c|c|c|c|}
\hline \multirow[b]{2}{*}{$\begin{array}{c}\text { SEGMENT } \\
\text { NO. }\end{array}$} & \multirow[b]{2}{*}{$\begin{array}{l}\text { VESICLES/ } \\
\text { SEGMENT }\end{array}$} & \multirow[b]{2}{*}{$\begin{array}{l}\text { Cumulative } \\
\text { VESICleS }\end{array}$} & \multicolumn{2}{|c|}{ USING INDIVIDUAL SEGMENTS } & \multicolumn{3}{|c|}{ USING CUMULATIVE SEGMENTS } \\
\hline & & & $\begin{array}{l}\text { Estimated } \\
\text { vesicles/ } \\
\text { fruit }^{\mathrm{a}}\end{array}$ & $\begin{array}{c}\% \text { difference } \\
\text { from actual } \\
\text { total }\end{array}$ & $\begin{array}{l}\text { Average } \\
\text { vesicles / } \\
\text { segment }^{\mathrm{b}}\end{array}$ & $\begin{array}{c}\text { Estimated } \\
\text { vesicles/ } \\
\text { fruit }^{c}\end{array}$ & $\begin{array}{c}\% \text { difference } \\
\text { from actual } \\
\text { total }\end{array}$ \\
\hline 1. & 161 & 161 & 1,449 & -35.1 & 161 & 1,449 & -35.1 \\
\hline$\ldots \ldots \ldots$ & 290 & 451 & 2,610 & 17.0 & 226 & 2,030 & -9.0 \\
\hline 3. & 321 & 772 & 2,889 & 29.5 & 257 & 2,316 & 3.8 \\
\hline 4. & 190 & 962 & 1,710 & -23.4 & 240 & 2,164 & -3.0 \\
\hline$\ldots$ & 349 & 1,311 & 3,141 & 40.8 & 262 & 2,360 & 5.8 \\
\hline$\ldots \ldots \ldots$ & 236 & 1,547 & 2,124 & -4.8 & 258 & 2,320 & 4.0 \\
\hline $7 \ldots$ & 224 & 1,771 & 2,016 & -9.6 & 253 & 2,277 & 2.1 \\
\hline 8. & 255 & 2,026 & 2,295 & 2.9 & 253 & 2,279 & 2.2 \\
\hline $9 \ldots \ldots \ldots \ldots$ & 205 & 2,231 & 1,845 & -17.3 & 248 & 2,231 & 0 \\
\hline
\end{tabular}

NoTE. - Total vesicles $=2,231$; total segments $=9$, and average vesicles/segment $=247.9$.

${ }^{a}$ Estimated vesicles/fruit obtained from multiplying the total number of fruit segments by vesicles/segment.

${ }^{b}$ Average vesicles/segment obtained from dividing the cumulative vesicles by the number of segments counted to this point.

${ }^{\mathrm{c}}$ Estimated vesicles/fruit obtained from multiplying the total number of fruit segments by the average vesicles/segment. 
TABLE 4

INFLUENCE OF ENVIRONMENT ON THE NUMBER OF VESICLES PRODUCED IN LEMON FRUITS

\begin{tabular}{|c|c|c|c|}
\hline Genus, species, cultivar ${ }^{a}$ & Vesicles/fruit $^{\mathrm{b}}$ & Seeds/fruit & Vesicles/seed \\
\hline \multicolumn{4}{|l|}{ Citrus limon cv Eureka: } \\
\hline Grown outdoors..... & $2,490.5 \pm 70.074$ & $22.2 \pm 1.887$ & $114.0 \pm 8.210$ \\
\hline Greenhouse grown .. & $2,979.2 \pm 53.021 \mathrm{~S}$ & $0 \pm 0$ & $\pm 0^{c}$ \\
\hline \multicolumn{4}{|l|}{ Citrus meyerii cv Improved: } \\
\hline Grown outdoors ........... & $2,727.0 \pm 66.463$ & $12.0 \pm 1.000$ & $230.9 \pm 22.300$ \\
\hline Greenhouse grown $\ldots$ & $3,390.0 \pm 50.748 \mathrm{~S}$ & $8.0 \pm 1.000$ & $437.0 \pm 53.280$ \\
\hline
\end{tabular}

${ }^{\text {a }}$ All fruits measured were $30 \mathrm{~mm}$ diameter.

${ }^{b}$ Averages and standard errors are presented. For each species, treatments means are significantly different at $5 \%(\mathrm{~S})$ or nonsignificant (no designation) using the $t$-test $(P<.05)$.

No seeds occurring in fruit to obtain a measurement.

the total number of vesicles occurring within citrus fruits was found to be related to genotype. Pummelos, grapefruits, and citrons contain the most vesicles per fruit as well as the most vesicles per segment. According to BARRETT and RHODES (1976) and SCORA (1975) pummelo, mandarin, and citron represent the oldest Citrus species. Crosses within these three Citrus species have given rise to many other commonly known Citrus species. Pummelos and citrons have the most vesicles per fruit (averaging 8,000 and 3,000-5,000, respectively) as well as the most vesicles per segment (averaging 400 and 270-460, respectively). Mandarins, on the other hand, contain fewer vesicles per fruit (averaging 2,000-2,300) and fewer vesicles per segment (averaging 200-260). Sweet orange, a cross between pummelo $\times$ mandarin (SCORA 1975), was found to correspondingly contain an intermediate number of vesicles per fruit (averaging 2,440-3,800) and per segment (averaging 243-400). The number of vesicles produced by orange fruit cultivars may be directly related to the degree of introgression with mandarin, or pummelo, or to backcrossing. Sour orange, also a cross between pummelo and mandarin (SCORA 1975), contains an intermediate number of vesicles per fruit (averaging 2,092) and per segment (averaging 202). Grapefruit, a cross between pummelo and sweet orange (SCORA 1975), exhibits a higher number of vesicles per fruit (averaging 3,000-3,900) and vesicles per segment (averaging 296-337) than sweet orange. Cultivar Imperial grapefruit is presumed to be a cross of sweet orange and grapefruit (HoDGSON 1967) and thus contains fewer vesicles per fruit (averaging 2,425 ) and vesicles per segment (averaging 189) than other grapefruits (table 1).

Recently, intact citrus juice vesicles have begun to be extracted and marketed in citrus juice products (MAEDA and IFUKU 1981). In Japan, the Satsuma mandarin is used exclusively in this process, primarily because of its availability. The Satsuma mandarin contains about $1,500-1,600$ vesicles per fruit. If the Valencia orange, which contains 3,500-
4,000 vesicles per fruit and is commonly grown in the United States, were substituted for Satsuma mandarin extraction yields would double. Citrus processors involved in extracting whole juice vesicles from fruits may benefit from counts of vesicles available in citrus fruits. Variation in taste and texture of citrus fruit pulp may also be related to the total number and shape-types of vesicles produced by fruit.

GolDSCHMIDT (1976) found that shaded citron fruits were larger and contained a thicker peel than fruits exposed to the sun. The basic shapes of most citrus fruits are determined prior to anthesis except in citrons, the shape of which is determined after anthesis (GOLDSCHMIDT 1976). Vesicle initiation is likewise determined after anthesis and is subject to alternative developmental processes. Juice vesicle primordia either terminate into an indistinct carpellary emergence or develop into the normal juice vesicles that are characteristically found in the fruit (BAIN 1958; SCHNEIDER 1968). We found that if fruit set occurs in a greenhouse an increase in the fruits' vesicle number occurs. These extra vesicles may be derived from preformed primordia that do not degenerate into carpellary emergences but continue to enlarge and develop "normally." Alternatively, these additional vesicles may arise from more primordia being initiated. Climate and environmental factors greatly influence the chemical composition of the pulp juice (Boswell et al. 1982; REUTHER 1980). Chemical treatments might also be useful in altering the number of vesicles produced per fruit. Such applications would seem most appropriate when the vesicle primordia first appear in the fruit (about the time of anthesis).

The chemical composition of the endocarp in the citrus fruit changes during chronological and physiological aging (SINCLAIR and RAMSEY 1944; BAIN 1958). Vesicle chemical composition changes depend upon the location of the vesicles within the segment (GOTO and ARAKI 1983). Juice vesicles in the stem region of Sanbokan (C. sulcata Hort. ex Tak.) segments have greater total sugars, bound 
acids, carotenoids, flavonoids, and vitamin $\mathrm{C}$ than vesicles in the equatorial regions of the segment. Conversely, for free acids, total nitrogen, amino acids, and RNA the reverse was true (GоTо and ARAKI 1983). Similarly, other investigators have noted important chemical differences within the citrus fruit (HAAS and KLOTZ 1935; BARTHOLOMEW and SinClaIr 1941; SinClaIR and BARTHOLOMEW 1944; SINCLAIR and RAMSEY 1944; MARLOTH 1950). It should now be recognized that the shape-types and number of vesicles per segment, as well as their location within the segment, vary considerably and have not been considered in citrus chemical studies. Whether these vesicle parameters influence chemical composition studies remains to be determined.

\section{Acknowledgments}

We thank Drs. J. B. CARPEnTER and L. M. BLAKELY for critically reading the manuscript and Mr. E. M. NAUER and Dr. W. P. BITTERS for providing information and aid in obtaining plant material. Appreciation is extended to G. AsGEDOM for technical support during this study.

\section{LITERATURE CITED}

BAIN, J. M. 1958. Morphological, anatomical, and physiological changes in the developing fruit of the Valencia orange, Citrus sinensis (L.) Osbeck. Aust. J. Bot. 6:1-24.

BANERJI, I. 1954. Morphological and cytological studies on Citrus grandis Osbeck. Phytomorphology 4:390-396.

BarretT, H. C., and A. M. Rhodes. 1976. A numerical taxonomic study of affinity relationships in cultivated Citrus and its close relatives. Syst. Bot. 1:105-136.

BARTHOLOMEW, E. T., and W. B. SinClair. 1941. Unequal distribution of soluble solids in the pulp of citrus fruits. Plant Physiol. 16:293-312.

Boswell, S. B., E. M. NaUeR, and D. R. AtKIn. 1982. Effect of tree density on fruit quality, temperature, light penetration, growth, and production of old-line 'Atwood' navel orange trees. J. Am. Soc. Hort. Sci. 107:60-65.

CogGins, C. W., Jr., H. Z. Hield, and S. B. Boswell. 1960. The influence of potassium gibberellate on Lisbon lemon trees and fruit. Proc. Am. Soc. Hort. Sci. 76:199-207.

FORD, E. S. 1942. Anatomy and histology of Eureka lemon. BOT. GAZ. 104:228-304.

GolDSCHMIDT, E. E. 1976. Factors determining the shape of citrons. Israel J. Bot. 25:34-40.

Goto, A., and C. ARAKI. 1983. Chemical compositions and internal anatomy of the gelated and granulated juice sacs of sanbokan (Citrus sulcata hort. ex Takahashi) fruit. J. Japanese Soc. Hort. Sci. 52:316-324.

HaAs, A. R. C., and L. J. KLotz. 1935. Physiological gradients in citrus fruits. Hilgardia 9:181-217.

HodgSON, R. W. 1967. Horticultural varieties. Pages 431-591 in W. Reuther, H. J. WebBer, and L. D. Batchelor, eds. The citrus industry. Vol. 1. Rev. ed. Division of Agricultural Science, University of California, Berkeley.

MAEDA, H., and Y. IFUKU. 1981. Tendency for production and consumption of citrus fruit juices in Japan, especially pro- duction of fruit drinks with juice sacs. Proc. Int. Soc. Citriculture 2:859-861.

MARLOTH, R. H. 1950. Citrus growth studies. II. Fruit-growth and fruit internal quality changes. J. Hort. Sci. 25:235-248.

NII, N., and B. G. COOMBE. 1988. Anatomical aspects of juice sacs of Satsuma mandarin in relation to translocation. J. Japan. Soc. Hort. Sci. 56:375-381.

OsawA, I. 1912. Cytological and experimental studies in citrus. J. Coll. Agric. Imp. Univ. Tokyo. 4:83-116.

REED, H. S. 1930. The swelling of citrus fruits. Am. J. Bot. 17:971-982.

REUTHER, W. 1980. Climatic effects and quality of citrus in the tropics. Proc. Am. Soc. Hort. Sci., Trop. Reg. 24:15-28.

SAUER, M. R. 1953. Need for adequate soil moisture in Feb.May shown by Valencia measurements at Merbein. Citrus News 28:138-139, 141.

SCHNEIDER, H. 1968. The anatomy of citrus. Pages 1-84 in W. REUTHER, L. D. BATCHELOR, and H. J. WEBBER, eds. The citrus industry. Vol. 2. Rev. ed. Division of Agricultural Science, University of California, Berkeley.

SCORA, R. W. 1975. On the history and origin of citrus. Bull. Torrey Bot. Club 102:369-375.

SinClaiR, W. B., and E. T. BARTHOLOMEW. 1944. Effects of rootstock and environment on the composition of oranges and grapefruit. Hilgardia 16:125-176.

SinclaiR, W. B., and R. C. RAMSEY. 1944. Changes in the organic-acid content of Valencia oranges during development. Bот. GAZ. 106:140-148.

Swingle, W. T., and P. C. REeCE. 1967. The botany of citrus and its wild relatives. Pages 190-430 in W. ReutHeR, H. J. WEBBER, and L. D. BATCHELOR, eds. The citrus industry. Vol. 1. Rev. ed. Division of Agricultural Science, University of California, Berkeley. 